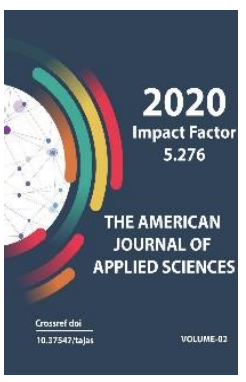

\title{
Stratigraphic Characteristic Devon System Of Mountain Kuldzhuktau (South Tian-Shan)
}

\author{
Nodir Khairullaevich Davlatov \\ Head Of The Stratigraphic Party "Regional Geological Survey Expedition" Under The \\ Committee Of The Republic Of Uzbekistan For Geology And Mineral Resources, Uzbekistan
}

\section{ABSTRACT}

This article presents the results of long-term stratigraphic studies on the territory of the Kuldzhuktau mountains. Schemes for the division and correlation of Devonian deposits have been created based on complete biostratigraphic data that most effectively reflect the geological age of local stratigraphic units and their reliable correlation with geological age. The tier units of the International Devonian Stratigraphic Scale are substantiated at the present stage of research.

Due to the widespread use of conodonts, it was possible to clarify the physical and age volumes, as well as the sequence of Devonian deposits in the territory of Kuldzhuktau, and almost completely reconstruct the Devonian section.

\section{KEYWORDS}

Devonian, stage, straton, Kuldzhuktau mountains, fauna, conodonts, biostratigraphic method.

\section{INTRODUCTION}

The relevance of the research substantiated the creation of a scheme of dissection and correlation of Devonian deposits in the Kuldzhuktau mountains in the Southern Tien Shan.
Tectonically, the Kuldzhuktau Mountains are a complex folded structure consisting of a series of narrow, highly compressed asymmetric folds with a sharply emphasized linear orientation of their axes in the northwest direction. The wings of the folds are broken by faults, most of which are faults 
and only a part are steeply dipping thrusts (Biske, 1996 [8]).

Several formations in the age range from Ordovician to Carboniferous take part in the geological structure of the Kuldzhuktau mountains, which are grouped into two tectonic plates linearly elongated in the latitudinal direction: autochthon (northern block) and allochthon (southern block). These plates have a similar structure with slight differences in the base and upper parts of the section (Mirkamalov et al., 2020 [23]).

The aim of the research is to correlate the Devonian deposits of the Kuldzhuktau Mountains on more complete biostratigraphic data that most effectively reflect the geological age of local strata and their reliable correlation with the longline units of the International Devonian Stratigraphic Scale at the present stage of research.

\section{METHODOLOGY}

Stratigraphic studies for the study of Devonian deposits in the territory of the Kuldzhuktau mountains, field research was carried out during 2015-2017. by employees of the Stratigraphic Party, the State Unitary Enterprise "Regional Geological Survey Expedition" under the Committee of the Republic of Uzbekistan on Geology and Mineral Resources.
In the world of research on the definition of Devonian conodont biostratigraphy were engaged: Bassler, 1925 [6]; Branson and Mehl, 1933 [9]; Philip, 1966 [26]; Carls and Gandl, 1969 [11]; Pedder et al. 1970 [25]; Klapper and Philip, 1971 [16]; Boersma, 1973 [7]; Wang et al. 1974 [28] Weddige and Ziegler 1979 [29]; Bai, et al., 1979-1994 [3]; Mawson 1987 [21]; Bultynck, 1989 [10]; Talent and Mawson 1999 [27]; Bardashev et al., 2002 [5]; Mawson and Talent 2003 [22]; Ma, et al., 2009 [18]; Martínez-Pérez, and Valenzuela-Ríos, 2014 [20]; Lu, et al., 2016 [17] and many other researchers.

For the territory of Central Asia, the characteristics of the Devonian conodont biostratigraphy are reflected in the works: Mashkov, 1978 [19]; Kim, et al., 1978-2012 [1315]; Bardashev, 1986 [4]; Apekina 1989 [4]; Yolkin et al., 1994 [30], 1997 [31], 2008 [32], 2011 [33]; Nikolaeva et al., 2017 [24] and others.

By comprehensively substantiating the age volumes of the Lower and Middle Devonian sediments using the data obtained on conodonts, it was possible to significantly clarify their age volumes, and significantly enrich the arsenal of the biostratigraphic method for decoding the stratigraphic sequence of strata in the tectonically complex regions of the Kuldzhuktau Mountains (Fig. 1). 


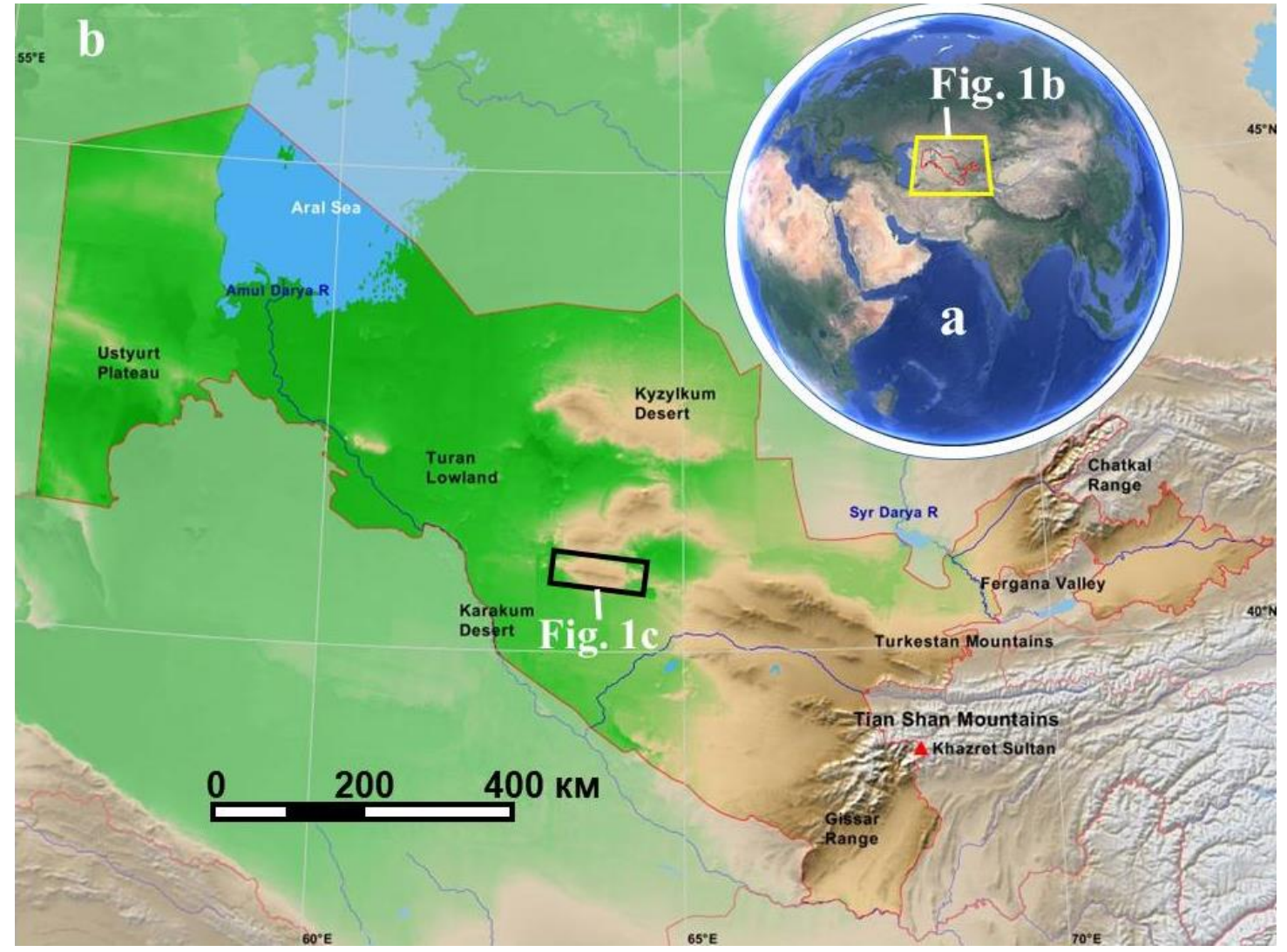

Fig.1. Physical map of research areas: a- Republic of Uzbekistan and adjacent territories in the world; b-hypsometric map of the Republic of Uzbekistan and adjacent territories; from the study areas of the Kuldzhuktau Mountains.

\section{RESULTS AND DISCUSSION}

The Devonian formations are the most widespread and are represented by essentially marine carbonate, siliceous-carbonate, terrigenous-carbonate-siliceous and terrigenous deposits.

Devonian deposits are represented by all three divisions; divided into the Turkmentau Formation of the Lower Devonian, the Sultanbibin Formation of the Lower-Middle Devonian, the Arapkazgan Formation of the Lower-Upper Devonian, the Shaydaraz and Beltau Formations of the Upper Devonian and the Turkmenkazgan Formation of the Upper Devonian. They are exposed in the Beltau mountains, in the area of the Dzhangeldy village, west, east and north of the Tozbulak intrusion, in the areas of the Uchkuduk, Shaydaraz, Sultanbibi, Arapkazgan, Izakuduk, Bashguzhumdy wells, in the Guzhumdy mountains and with minor outcrops in the regions of the Kuyng uplands in the form of Tuzkoy and Tuzkoy sections of latitudinal and sub-latitudinal strike. All of these formations are in tectonic contact with the rocks of the Upper Silurian and Middle Carboniferous.

\section{Turkmentau Formation - D1l-p tr}

The Turkmentau Formation of the Early Devonian age was identified by Ya.B. Aisanov, A.l. Egorov (1978) as part of three units: 1) dark gray, black limestones $(150 \mathrm{~m})$ with the benthic fauna of the Early Devonian; 2) white, 
light gray, spotted limestones with interlayers of dolomites (300 m); 3) patterned, brecciated, light gray massive limestones (250 $\mathrm{m})$.

As a result of biostratigraphic studies carried out by the authors, in the limestones of unit 1 , in addition to the known benthic fauna, finds of conodonts were established, specifying the age of the first unit of the formation in the volume of the Lochkov - the Prague interval of the Early Devonian. Late Devonian Famennian conodonts have been identified in limestones of patterned, brecciated light gray members 2 and 3. Thus, the Turkmentau Formation included two strata of different age with different lithological composition. Based on the new data obtained, deposits of members 2 and 3 (Aisanov et al., 1978), containing conodonts of the Late Devonian, are distinguished into the new Turkmekazgan stratum of the Upper Devonian. The Turkmentau Formation remains in the volume of Member 1 of the Lokhkov-Prague age.

The Turkmentau Formation is represented by lumpy-micritic limestones, stratified, lumpy, dark gray $(430 \mathrm{~m})$, which are shallow-water formations of the carbonate platform. It is exposed in the form of elongated sections of latitudinal and sublatitudinal strike in the west of the Kuldzhuktau mountains on the southern slope of the Beltau mountains, on the southern slopes of the Tuzkoy uplands, west and east of the village. Dzhangeldy, west of the Tozbulak granitoid intrusion; in the east of the Kuldzhuktau mountains southeast of the Bashguzhumdy well. The formation has tectonic relationships with the underlying Upper Silurian sediments and stratigraphically normal contacts with the overlying sediments of the Lower-Middle Devonian Sultanbiba
Formation. The total thickness is 430 m.Of organic remains, they contain tabulates: Favosites ex gr.socialis Sokolov, Favosites preplacenta Dubatolov, Pachyfavosites cylindricus Yanet, Pachyfavosites ex gr. kozlovskii Sokolov, Striatopora tenuimuralis Mironova, characteristic of the LochkovPrague period of the early Devonian; brachiopods - Sieberella aff. sieberi (Buch), Punctatrypa cf. perpolita (Khodalevich), Plesicarinatina cf. submala (Khodalevich) the Prague-Emsian interval of distribution; conodonts - Belodina sp., Icriodus sp., Hindeodella sp., Panderodus sp., Paltodus sp., Eognathodus sulcatus forms characteristic of the Prague time. The above complex of organic remains allows us to consider the age of the Turkmentau Formation in the scope of the Lokhkovsky and Prague ages of the Early Devonian.

\section{Sultanbibin Formation - D1-2 sl}

The Sultanbibin Formation is exposed in the form of elongated sections of latitudinal and sublatitudinal strike at the western end of the Beltau Mountains, west and east of the Dzhangeldy village, west of the Tozbulak intrusion, in the areas of the Uchkuduk, Aktosta, Sultanbibi, Izakuduk wells, in the basin and eastern parts of the Arapkaz mountains of Gujumda. The formation has stratigraphically normal contacts with the underlying deposits of the Turkmentau Formation west of the Tozbulak intrusion. The top contact is not known. South of the count. The Izakuduk Sultanbibin Formation adjoins the upper part of the Arapkazgan Formation by tectonic contact. The section of the Sultanbibin Formation is characterized by a complex tectonic structure with widespread folding and numerous faults (Fig. 2). 


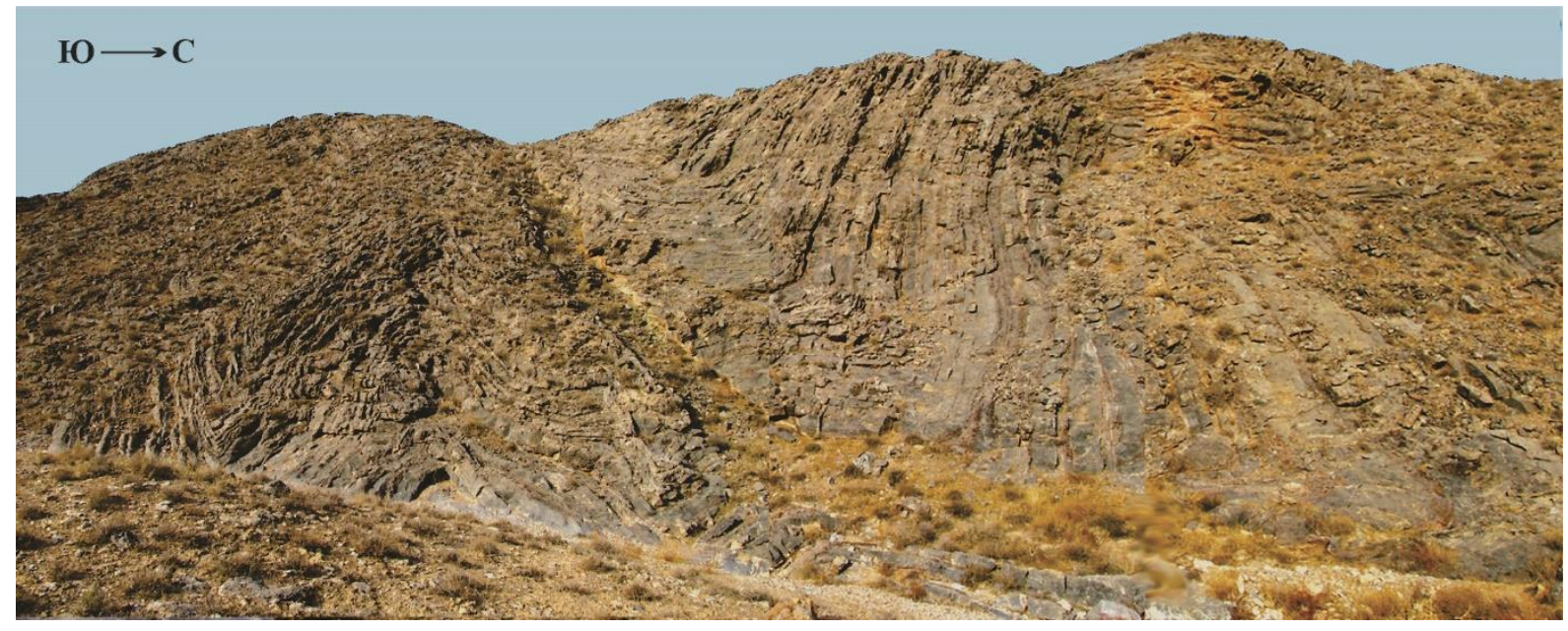

Figure: 2 . Folded and ruptured deformations in the sediments of the lower part of the Sultanbibin suite northwest of the Uchkuduk well

Previously, the age of the formation was determined by the Emsian age (Ya.B. Aisanov and A.I. Egorov, 1984), however, the presence of conodonts in the sediments of the formation made it possible to clarify its age.

According to lithological features and faunistic filling, the deposits of the formation are divided into two parts.

The lower part ( $300-400 m)$ is represented at the base by dolomitic reddish-brown limestones, higher crinoid-detrital limestones, organogenic, multilayered, gray, dark gray, with interlayers, lenses and nodules of dark brown siliceous rocks and crimson-brown calcareous siltstones ... This part of the formation is characterized by a complex of tabulatomorphic corals - Pachyfavosites ex gr. preplacenta (Dubatolov), Squameofavosites obliquespinus (Tchernychev), Pachyfavosites rariporosus Dubatolov, Favosites gregalis Porfiriev, Paraheliolites vulgaris (Tchernychev), Oculipora zeravshanica Kim, Favosites sublatus Dubatolov, Fav. ex gr. gregalis Porfiriev, Fav. calioporoides Kim, Fav. ex gr. karpinskyi Yanet, Fossoporella hamidulica Kim, Pachycanalicula ex gr. dentata Mironova Emsian age; brachiopods Gypidula sp., Schizophoria sp. indet, Chonetes sp., Areostrophia sp., Atrypa sp., Carinatina sp., Spirigerina sp., Biconostrophia sp., Howellella sp., Hysterolites sp., Eospirifer sp. the Prague-Emsian interval of distribution; conodonts - Eognathodus sulcatus Philip, Polygnathus kitabicus Yolkin et al., P. nothoperbonus Mawson, P. ex. excavatus Carls et Gandl, P. ex. gronbergi Klapperet Johnson, P. serotinus Telford, P. kimi Mashkova et Apekina, P. inversus Klapper et Johnson, P. laticostatus Klapper et Johnson, P.pannonicus Mashkova et Apekina, Ozarkodina boucoti Klapper, Oz. prolata Mawson zone spacing kitabicus-patulus эмсского яруса. The above complex of organic remains in the lower part of the Sultanbibin Formation indicates the Emsian time of sedimentation.

The upper part of the Sultanbibin Formation is exposed in the form of tectonic blocks of sublatitudinal strike east of the Dzhangeldy village, north of the Uchkuduk well, southwest and south of the Izakuduk well, and in the eastern part of the Guzhumdy mountains. It is represented by gray micritesparite limestones, silicified, stratified, platy, with an admixture of clay-dolomite material and brown clay smears along the bedding planes. Siliceous rocks are developed in the form of lenticular interlayers and nodules. 
The rocks on the surface are reddish-brown with a pinkish tint. The thickness of the interlayers is $0.5-5-6 \mathrm{~cm}$, the lenses are up to $20 \mathrm{~cm}$ in swells and up to $1.5 \mathrm{~m}$ long. horizons with tabulatomorphic corals: Coenites sp., Thamnopora sp., Crassialveolites sp. Of the conodont deposits found in these sediments, species Polygnathus serotinus Telford, Polygnathus aff. linguiformis subsp.indet, Polygnathus pugiunculus Mawson, Polygnathus aff. parawebbi Chatterton, Polygnathus aff. eiflius Bischoff et Ziegler indicate the Eiffelian time interval, and the species, Polygnathus ziglerianus Weddige, Polygnathus aff. limitaris Ziegler et Klapper, Polygnathus pugiunculus Mawson, Icriodus beckmanni sinuatus (Klapper, Ziegler et Mashkova), characteristic of Givetian time. In general, the complex of the Condonts, in the upper part of the Sultanbibin Formation, indicates the Eifel-Givetian age of the deposits, the interval of the partitushemiansatus zones.

The largest area of distribution of deposits of the upper part of the Sultanbibin Formation is in the eastern part of the Guzhumdy Mountains. Here they are represented by interbedded limestones, siliceous rocks and calcareous siltstones. Limestones are coarsemedium-grained, crinoid with inclusions of flint fragments with nodules, nodules, interlayers of pinkish-brown siliceous rocks, and single fragments of colonies of stromatoporates and tabulata of unsatisfactory preservation. The conodonts found in this part of the formation are represented by the following species: Pseudooneotodus bicornis Drygant, Pseudooneotodus beckmanni Bischoff et Sannemanni, Neopanderodus aequabilis Telford, Panderodus sp., Polygnathus aff. serotinus Telford, Belodella cf. resima (Philip) $30 \mathrm{H}$ serotinus-ensensis Eiffelian distribution interval; complex of conodonts, represented by the following species: Polygnathus? coelatus Bryant, Pol. linguiformis mucronatus
Wittekindt, Pol. linguiformis gamma Pol. linguiformis gamma morphotype Bultynck, Pol. cf. linguiformis weddigei Leuteritz et Ziegler in North America (Genesse Formation) covers the interval of varcus-asymmetricus zones and corresponds to the Givetian and Lower Frasnian stages; a similar distribution is observed in Morocco and Germany. A complex of conodonts, consisting of the following species: Polygnathus aff. linguiformis linguiformis Hinde, Pol. aff. linguiformis Hinde, Pol. linguiformis pinquis Weddige, Pol. aff. uyenoi Bardashev, Pol. collieri Mophotype 2 Aboussalam et Becker is characteristic of the boundary layers of the Givetian Stage of the Middle Devonian and Frasnian Stage of the Upper Devonian. The data presented allow us to interpret the age of the upper part of the Sultanbiba Formation in the volume of the Eifelian-Givetian ages, while the possibility of the presence of deposits of the lower Upper Devonian is not excluded. The estimated thickness is approximately 150-200 m.

According to the conodonts, the age of the Sultanbibin Formation is dated to the extent of the Ems-Eifel-Givetian centuries. The thickness is $400-500 \mathrm{~m}$. Contact with overlying sediments is tectonic everywhere.

\section{Arapkazgan Formation - D1-3 ak}

The Arapkazgan Formation is exposed in the form of separate sections and narrow strips of latitudinal and sublatitudinal strike east of the village of Dzhangeldy, north of the Uchkuduk well, south of the Aktosta, Sultanbibi, Turkmenkazgan, Izakuduk wells, in the basin of the Arapkazgan river and on the Kopshak Upland. According to Ya.B. Aisanov, A.I. Egorov (1978), the formation transgressively overlies the sediments of the Sultanbibin suite to the south east of the village of Dzhangeldy and south of the Izakuduk well, in the areas of the Aktosta, Sultanbibi and Shaidaraz wells; in other places the contacts are tectonic. The age of the formation was previously 
determined in terms of the volume of the late Eiffel-living.

During biostratigraphic studies of the Kuldzhuktau mountains, thanks to the use of conodonts, a new group of fauna for this region, from separate outcrops, blocks of the Arapkazgan Formation, it was possible to reconstruct a consistent, faunistically substantiated stratigraphic section, clarify the lithological-material composition, establish the physical and age volumes, and determine the genesis of the formation's deposits. Transgressive occurrence was not confirmed. It has been established that the lower Arapkazgan Formation is an age analogue of the lower part of the Sultanbibin Formation. In general terms, the reconstructed section consists of carbonate-siliceous rocks, with an insignificant amount of terrigene. Formed in deep areas of a remote shelf or continental slope at the end of the Early - Late Devonian.

The lower part of the formation is traced from the Arapkazgan Say basin in the west to the Izakuduk well in the east as separate isolated blocks in the Arapkazgan Formation distribution. The greatest thickness of the sediments is found in the area of the Arapkazgan say and is approximately $180 \mathrm{~m}$. It is represented by quartz-siliceous-jasper rocks, thin-medium-bedded, platy, light gray, whitish, lumpy with single interlayers of hiddengrained thin-bedded, platy, light-gray limestones and calcareous crimson-gray siltstones. This part of the formation has a peculiar appearance and is easily recognizable by its light gray, whitish color and texture and structural features.

In these rocks to the south of the Izakuduk well, the presence of Polygnathus excavatus excavatus conodonts was established Carls et Gandl, Pol. nothoperbonus Mawson, Pol. inversus Klapper et Johnson, Pol. aff. serotinus Telford, Pol. kimi Mashkova et
Apekina of the Late Emsian, interval of inversus-serotinus zones. The age of the lower member of the Arapkazgan Formation is determined in the volume of the Obisafite layers of the Late Emsian - Early Devonian. Contact with the surrounding tectonic formations.

The Eiffel-Givetian deposits of the Arapkazgan Formation are exposed east of the village. Dzhangeldy, north of the Uchkuduk well and south of the Izakuduk well. They are represented by quartz-siliceous rocks and granular limestones, multilayered with silicified organogenic detritus, nodules of siliceous rocks with a conodont complex: Tortodus cf. trispinatus Abussalam, Polygnathus aff. eiflius Bischoff et Ziegler, P. aff. limitaris Ziegler et Klapper, P. aff. costatus Klapper, P. cf. serotinus Telford, P. linguiformis sub sp. indet, P.pugiunculus Mawson, P. evidens Klapper et Lane, Neopanderodus aequalis Telford, Hindeodella priscilla Stauffer, Webbinelloidea? sp.indet of the Eiffel-Givetian time, the interval of the partitus-disparilis zones, and conodonts: Polygnathus subsymmetricus Aboussalam et Becker, Polygnathus dubius Hinde, Polygnathus pennatus Hinde, Nothognatella sp., characteristic of the boundary layers of the Lives and Frances of Europe and North America in the volume of the Givetian Age of the Middle Devonian. The greatest thickness of this interval is noted to the south of the Izakuduk well, 140m.

The Upper Devonian component of the Arapkazgan Formation is exposed east of the village. Dzhangeldy and in the area of the Izakuduk well. The upper part of the Sultanbibin Formation occurs along a fault on the outcrops.

Fransk deposits are represented by alternating detrital limestones, layered with thin-layered black siliceous jasper rocks and interlayers of red-brown calcareous siltstones containing conodonts: Enantiognatus? 
gantharii Ziegler, Polygnathus dengleri Bisch et Ziegler, P. dubius Hinde, P. uchtensis Ovnatanova et Kuzmin, P. aff. morgani Klapper et Lane, P. alatus Haddle, P. aequalis Klapper et Lane, P. linguiformis sub sp.indet, P. housei Aboussalam, P. gracilis Klapper et Lane, P. dengleri Bischoff et Ziegler, P. aff. timorensis Klapper, Philip et Jackson, P. pennatus Hinde, Klapperina disparalvea (Orr et Klapper), Neoprioniodus alatus Hinde, Mesotaxis falsiovalis Sandberg, Ziegler et Bultynck, M. asymmetricus (Bischoff et Ziegler magheva), Tischoff et Ziegler magheva, Nothognchernova ziegleri (Clark et Ethington), Palmatolepis transitans Muller, Pal. hassi Muller et Muller, Pal. gigas semichatovae Ovnatanova, Pal. g. gigas Muller et Joungquist, Pal. plana Ziegler et Sandberg, Pal. punctata (Hinde), Pal. aff. limitaris Ziegler et Klapper, Pal. rhenanus marija Huddle, Pal. rhenana rhenana Bischoff, Pal. aff. subrecta Muller et Joungquist, Pal. aff. ederi Ziegler et Sanderg, Pal. barba Ziegler et Sanderg, Pal. orbicularis Ovnatanova et Kuzmin, Pal. mucronata Klapper, Kuzmin et Ovnatanova, Pal. cf. kleyserlingi Kuzmin, Pal. orlovi Khruscheva et Kuzmin, Pal. ormistoni Klapper, Kuzmin et Ovnatanova, Pal. kireevae Ovnatanova, Pal. muelleri Klapper et Foster of the French age; power $58 \mathrm{~m}$.

The Famennian deposits of the Arapkazgan Formation have a limited distribution in the form of narrow thin strips of sub-latitudinal strike east of the Dzhangeldy settlement and in the form of thin outcrops along the fault with terrigenous rocks of the Taushan Formation of the Carboniferous southwest of the Izakuduk well. These sediments contain conodonts: Palmatolepis schleizia Helms, Palmatolepis inflexoides Ziegler, Pseudopolygnathus marburgensis marburgensis Biscoff et Ziegler, Polygnathus sp. indet of the Famennian Stage, the interval of the rhomboidea - postera zones of Europe and Central Asia.
The above conodont assemblages, which characterize the sediments of the formation, make it possible to determine its age in the volume of the Late Emsian - Zhivite - FranaFamen. The formation is $300-330 \mathrm{~m}$ thick. Contacts with the surrounding formations of the Sultanbiba and Taushan formations are tectonic. The interrelationships between members within the formation are often tectonic as well, which are most likely the result of thrust-thrust movements in the postHercynian time.

\section{Beltau Formation - D3 bl}

The Beltau Formation is exposed in the form of scattered narrow strips of sub-latitudinal strike southeast of the Bashguzhumdy well and northwest of the Dzhangeldy village. The relationship with the surrounding formations is tectonic.

Southeast of the Bashguzhumdy well, the section of the formation is represented by micritic, micrite-sparite, organogenic-detrital, light gray and gray limestones, thin and medium bedded. The age of the formation for the microfauna complex was earlier dated to the Tournaisian of the Early Carboniferous (Aisanov et al., 1978). However, due to the fact that the boundary between the Devonian and the Carboniferous was later adopted by the International Stratigraphic Commission at the level of the base of the Siphonodella sulcata conodont zone, everything that previously belonged to the lower Tournaisian stage of the Lower Carboniferous is now accepted to be attributed to the Famennian stage of the Upper Devonian. Based on this, the microfauna complex, which was previously considered Tournaisian, is now interpreted by microfaunal paleontologists as Late Devonian. The validity of this interpretation is confirmed by the findings in these conodont deposits: Palmatolepis hassi Muller et Muller and Pa. punctata (Hinde) Frasnian. 


\section{Shaydaraz Formation - D3 šd}

The Shaydaraz Formation of light and dark gray, banded, thick-bedded $(\sim 100 \mathrm{~m})$ limestones with the crinoid fauna of the Late Devonian age was identified by Ya.B. Aisanov and A.l. Egorov (1978) as a separate area $2 \mathrm{~km}$ southwest of the Shaydaraz well. As a result of biostratigraphic studies, fragments of this formation were found in the area of the Shaydaraz well, in the contour of the Turkmentau suite of the Lower Devonian (Fig.
3), where gray, light gray to white limestones are exposed, banded, in places reticular, sometimes spotted, multi-layered, massive, marbleized with conodonts: Palmatolepis cf. proversa Ziegler, Paltodus sp. common in the interval of the falsiovalis-linguiformis zones of the Frasnian stage of Europe, the Urals, and Central Asia. The thickness is 400-500 m. In terms of lithological and textural features, the described deposits are close to the rocks of the Shaydaraz Formation.

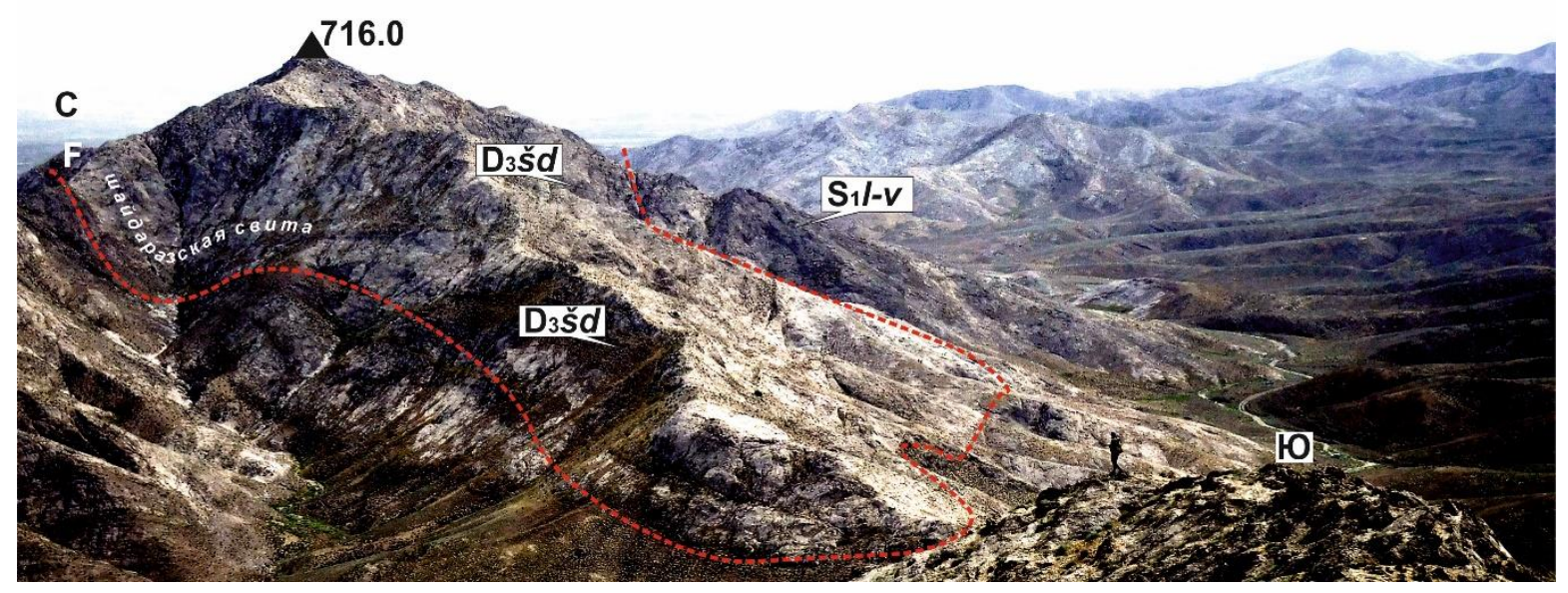

Figure: 3. Outcrop in the earth's surface of the Shaydaraz Formation east of Mount Bashguzhumdy

The Shaydaraz Formation also includes deposits that are exposed in the eastern part of the Kuldzhuktau Mountains, east of the Bashguzhumdy Mountain, in the carbonate massif that composes the upland from the El. 716.0 (fig. 3). Here, the section of the Shaydaraz Formation is represented by fine medium - grained, medium - thick bedded, massive, light gray limestones with lenticular accumulations of fine detrital crinoid detritus, highly fractured, marbleized, up to $200 \mathrm{~m}$ thick. The rocks are characterized by conodonts: Palmatolepis gracilis sigmoidalis Ziegler, Pal. aff. glabra Ulrich et Basler, Pal. rugosa rugosa Branson et Mehl, Pal. glabra glabra Ulrich et Basler, Pal. gracilis sub sp. indet, Pal. minuta minuta Branson et Mehl [9], Pal. minuta elegantula Wang et Ziegler, Pal. minuta wolsckae Szulezewski, Pal. glabra prima Ziegler et Haddle, Polygnathus znepolensis Spassov, Pol. aff. communis (Branson et Mehl), Pol. znepolensis Spassov, Pol. perplana Branson et Mehl, Nothognatella sp., Trichonodella (Branson et Mehl) of the Famennian age. The deposits underlying the Shaydaraz Formation are unknown. The relationship with the Middle Carboniferous Taushan Formation is tectonic.

Turkmenkazgan strata - D3 tk 
The Turkmenkazgan strata is distinguished for the first time in the composition of finemedium-grained limestones, wavy, lenticularirregularly banded, patterned, mosaic gray, light gray with horizons of consedimentation limestone breccia. Brecciated limestones consist of angular, non-rounded, semirounded fragments ranging in size from 0.5 $\mathrm{cm}$ to $1.5 \mathrm{~m}$, white, light gray and dark limestones in a gray, light gray limestone groundmass. Contacts with surrounding sediments are unclear or tectonic.

According to the data of Ya.B. Aisanov, A.I. Egorov (1978), these deposits made up the 2nd and 3rd members of the Turkmentau Formation and dated to Prague time. During biostratigraphic studies, Late Devonian conodonts were identified from the described deposits. The peculiar appearance of carbonate rocks, significant apparent thickness (up to $1000 \mathrm{~m}$ ) and wide distribution, served as the basis for the identification of a new subdivision of the Turkmenkazgan strata. The name was given from the Turkmenkazgan well located on the southern slope of the middle part of the Kuldzhuktau mountains. The strata is exposed in the form of scattered outcrops of sublatitudinal strike in the regions to the west and east of the village of Dzhangeldy, north of the Uchkuduk and Ayakgujumli wells, west of the Shaydaraz well, south of the Aktosta and Sultanbibi wells, in the Turkmentag and Guzhumdy mountains; the width of the outcrops ranges from 0.7 to $1.2 \mathrm{~km}$ and the length from 5 to $10-12 \mathrm{~km}$.

The age of the Turkmenkazgan strata is dated by us as the Late Devonian on the basis of isolated and definite conodonts. So north of the stake. Uchkuduk, the conodonts of Bispathodus sp., Palmatolepis cf.quadrantinodosa Branson et Mehl, Palmatolepis cf.minuta Branson et Mehl, Polygnathus sp.indet, Polygnathus cf.valentinae Kuzmin, Famennian, Upper
Devonian. $5.8 \mathrm{~km}$ northeast of the count. Uchkuduk, conodonts Palmatolepis minuta loba Helms (sample 706/4), characteristic of the Famennian deposits of the Upper Devonian, were identified.

In the eastern part of the Kuldzhuktau mountains in the east of the Guzhumdy mountains, in the deposits of the Turkmenkazgan strata, the presence of conodonts - Mesotaxis sp. indet, Polygnathus sp. indet, Tortodus sp.indet, Palmatolepis sp. indet, referring to the forms characteristic of the Givetian and Frasnian boundary layers.

The presented data on conodonts make it possible to interpret the age of the Turkmenkazgan sequence in the volume of the Frasnian and Famennian centuries of the Late Devonian. At the same time, there is no reliable information about the underlying and overlying sediments of the sequence, the nature of the relationships between the coeval formations of the Shaydaraz, Beltau and Upper Devonian parts of the Arapkazgan formations is not entirely clear. In facies terms, the deposits of the Turkmenkazgan strata were most likely formed on the outskirts of the carbonate platform from the side of the open sea basin (Kim, et al., 19782012 [13-15]; Yolkin et al., [33]).

Middle Devonian. The Eifelian and Givetian tiers are undivided (Sogdian horizon). Arapkazgan Formation.

In the lower part, it consists of thin-bedded black siliceous-quartz jasper rocks with sharp lenses of limestone ( $80 \mathrm{~m}$ thick). The middle part is composed of interbedded limestones, siliceous-quartz jasper rocks and shales (30 $\mathrm{m})$. The upper part ( $40 \mathrm{~m}$ ) is formed mainly by thin and medium platy gray and dark gray siliceous-quartz layers with single lenses of black limestones at the base. It is noted that the lithological composition of the section in the area is variable. In the central part of Kuldzhuktau, the section is mainly 
represented by alternating limestones, siliceous rocks and quartzite sandstones. The total thickness of the formation is $150 \mathrm{~m}$. Limestones and siliceous rocks of the lower and middle parts of the section contain stromatoporates Amphipora cf. ramosa Phill., Stachyodes cf. gracilis kuznetskensis Yavor., Caliapora cf. graciosa Yanet, Alveolites sp., Scoliopora sp., Chaetetes cf. salaincus Dubat., less often brachiopods and pelecypods Stringocephalus sp., Megalodon sp., which characterize the whole Eifelian-Givetian age of the deposits. It is noted that the Arapkazgan Formation overlaps the limestones of the Turkmentau and Sultanbibin Formations in a transgressive manner (Aisanov, Egorov, 1978) [1].

\section{CONCLUSION}

Based on the comprehensive substantiation of the age volumes of the Lower and Middle Devonian sediments using the data obtained on conodonts, it was possible to significantly clarify their age volumes, and significantly enrich the arsenal of the biostratigraphic method for decoding the stratigraphic sequence of strata in the tectonically complex regions of the Kuldzhuktau Mountains.

The results of biostratigraphic studies of a group of fauna as conodonts, new for the territory of the Kuldzhuktau mountains, have succeeded in establishing the facies confinement, the mutual relationships of local stratigraphic units existing here.

\section{REFERENCES}

1. Aisanov, Ya.B. Geological structure and main features of minerageny of the Paleozoic formations of the Kuldzhuktau mountains / Ya.B. Aisanov, A.l. Egorov; Resp. ed. I.V. Mushkin. - Tashkent: Fan, 1978 .-- 120 p.

2. Apekina L.S. New conodont from the Lower Devonian of the Zaravshan Range. // Paleont. zhurn. No. 1., Moscow, 1989. P. 119-120.

3. Bai, S. L., Ning, Z. S., Jin, S. Y., Ho, J. H., \& Han, Y. J. (1979). Devonian conodonts and Tentaculitids of Kwangsi, their zonation and correlation. Acta Scientiarum Naturalium Universitatis Pekinensis, 1, 99-118.

4. Bardashev, I. A. (1986). Emsian conodonts of the genus Polygnathus from central Tadzhikistan. Paleontological Journal, 20(2), 56-62.

5. Bardashev, I. A., Weddige, K., \& Ziegler, $W$. (2002). The phylomorphogenesis of some Early Devonian platform conodonts. Senckenbergiana lethaea, 82(2), 375-451.

6. Bassler, R. (1925). Classification and stratigraphic use of the conodonts. Geological Society of America Bulletin, 36(1), 218-220.

7. Boersma, K. T. (1973). Description of certain Lower Devonian platform conodonts of the Spanish Central Pyrenees. Leidse Geologische Mededelingen, 49(2), 285-301.

8. Biske Yu.S. Paleozoic structure and history of the southern Tien Shan // St. Petersburg: S. Petersburg University, 1996.

9. Branson, E. B., \& Mehl, M. G. (1933). Conodont studies no. 1: conodonts from the Harding Sandstone of Colorado; Bainbridge (Silurian) of Missouri; Jefferson City (Lower Ordovician) of Missouri. Missouri University Studies, 8, 5-72.

10. Bultynck, P. (1989). Conodonts from the La Grange Limestone (Emsian), Armorican Massif, north-western France. Courier Forschungsinstitut Senckenberg, $117,173-203$. 
11. Carls, P., \& Gandl, J. (1969). Stratigraphie und Conodonten des Unter-Devons der Östlichen Iberischen Ketten (NE-Spanien). Neues Jahrbuch für Geologie und Paläontologie Abhandlungen, 132(2), 155218.

12. Dalimov T.N., Shayakubov. T.Sh. Geology and minerals of the Republic of Uzbekistan. Tashkent "University". 1998. P-503. (pp.64-65)

13. Kim, A. I., Yolkin, E. A., Erina, M. V., \& Gratsianova, R. T. (1978). Field session of the international Subcommission on Devonian stratigraphy, Samarkand, USSR. In B. S. Sokolov \& V. G. Garkovets (Eds.), Type sections of the Lower and Middle Devonian boundary beds in Middle Asia, A Guide to Field Excursions. Atlas of paleontological plates. Supplement to Guide of the Field Excursion (pp. 1-55). Tashkent.

14. Kim A.I., Erina M.V., Apekina L.S., Lesovaya A.I. Biostratigraphy of the Devonian of the Zaravshan-Gissar mountain region, Izd. FAN, Tashkent, 1984, pp. 3-93.

15. Kim A. I., Erina M. V., Kim I. A., Salimova F. A., Meshchankina N. A., \& Rakhmonov U. D.. The Pragian-emsian event and subdivision of the emisian in the zinzilban and khodzha-kurgan sections. Newsletter No 27, 2012, p. 38-41.

16. Klapper, G., \& Philip, G. M. (1971). Devonian conodont apparatuses and their vicarious skeletal elements. Lethaia, 4(4), 429-452.

17. Lu, J. F., Qie, W. K., \& Chen, X. Q. (2016). Pragian and lower Emsian (Lower Devonian) conodonts from Liujing, Guangxi, South China. Alcheringa, 40(2), 275-296.

18. Ma, X. P., Liao, W. H., \& Wang, D. M. (2009). The Devonian system of China, with a discussion on sea-level change in South China. Geological Society, London, Special Publications, 314, 241-262.
19. T.V. Mashkova New conodonts of the resavis-optima zone from the Lower Devonian of the Urals and Zaravshan. // Paleont. Journal. No. 2, 1978. S. 91-96.

20. Martínez-Pérez, C., \& Valenzuela-Ríos, J. I. (2014). New Lower Devonian Polygnathids (Conodonta) from the Spanish Central Pyrenees, with comments on the early radiation of the group. Journal of Iberian Geology, 40(1), 141-155.

21. Mawson, R. (1987). Early Devonian conodont faunas from Buchan and Bindi, Victoria, Australia. Palaeontology, 30(2), 251-297.

22. Mawson, R., \& Talent, J. A. (2003). Conodont faunas from sequences on or marginal to the Anakie Inlier (Central Queensland, Australia) in relation to Devonian transgressions. Bulletin of Geosciences, 78(4), 335-358.

23. Mirkamalov R.Kh., Divaev F.K., Temurov B.Z., Uzokov R.T. (2020). About the tectonic structure of the Kuldzhuktau mountains. - Materials of the Republican Scientific and Technical Conference "Actual problems of geological education in the Republic and the prospects for the development of earth sciences", Tashkent, 2020. P.241-244. Online conference of Tashkent State Technical University.

24. Nikolaeva S., Kim A. I., Erina M. V. An early Emsian (Zlichovian) ammonoid assemblage from Sangibaland Mountain (Shakhimardan River Basin) (South Tien Shan, Kyrgyzstan), SENKENBERG, Published online: 29 July 2017.

25. Pedder, A. E. H., Jackson, J. H., \& Philip, G. M. (1970). Lower Devonian biostratigraphy in the Wee Jasper Region of New South Wales. Journal of Paleontology, 44(2), 206-251.

26. Philip, G. M. (1966). Lower Devonian conodonts from the Buchan Group, Eastern Victoria. Micropaleontology, 12(4), 441-460. 
27. Talent, J. A., \& Mawson, R. (1999). NorthEastern Molong Arch and adjacent Hill End Trough (eastern Australia); midPalaeozoic conodont data and implication. Abhandlungen der Geologischen Bundesanstalt, 54, 49-105.

28. Wang, Y., Yu, C. M., \& Wu, Q. (1974). Advances in the Devonian biostratigraphy of South China. Memoirs of Nanjing Institute of Geology and Palaeontology, 6, 1-71.

29. Weddige, K., \& Ziegler, W. (1979). Evolutionary patterns in Middle Devonian conodont genera Polygnathus and Icriodus. Geologica et Palaeontologica, 13, 157-164.

30. Yolkin, E. A., Weddige, K., Izokh, N. G., \& Erina, M. V. (1994). New Emsian conodont zonation (Lower Devonian). Courier Forschungsinstitut Senckenberg, 168, 139-157.

31. Yolkin E. A., Kim A. I., Weddige K., Talent J. A. and House M. R.. Definition of the Pragian/Emsian Stage boundary, Episodes, Vol. 20, No 4, 1997, 235-240.

32. Ёлкин Е. А., Ким А. И., Талент Дж. А. Девон Китабского государственного геологического заповедника, Путеводитель экскурсии, 2008, С 5-90.

33. Yolkin, E. A., Izokh, N. G., Weddige, K., Erina, M. V., Valenzuela-Ríos, J. I., \& Apekina, L. S. (2011). Eognathodid and Polyganthid lineages from the Kitab State Geological Reserve section (ZeravshanGissar moutainous area, Uzbekistan) as the bases for improvements of PragianEmsian standard conodont zonation. News of Palaeontology and Stratigraphy, $15,37-45$. 